\title{
Tryptophan and Indoleacetic Acid Transport in the Olive and Oleander Knot Organism Pseudomonas savastanoi (E. F. Smith) Stevens
}

\author{
By J. L. MARLOW AND T. KOSUGE \\ Department of Plant Pathology, University of California, \\ Davis, California, 956r6, U.S.A.
}

(Accepted for publication 24 January 1972)

\section{SUMMARY}

Transport studies revealed that Pseudomonas savastanoi readily takes up both tryptophan and indoleacetic acid, and that uptake was $\mathrm{pH}-$, temperature-, and energy-dependent. Uptake of tryptophan and indoleacetic acid appeared to be mediated by separate transport systems on the basis of differences in competitive interactions between tryptophan and indoleacetic acid, kinetics of transport, the $\mathrm{pH}$ range, and osmotic shock treatment of cells.

\section{INTRODUCTION}

Exchange of metabolites between host and pathogen undoubtedly plays an important role in host-parasite interactions. As the pathogen invades host tissue it takes up host constituents and utilizes them for nutrients. During interaction with the host, a pathogen may release biologically active compounds that account for production of symptoms characteristic of a particular disease. One such compound is indoleacetic acid (IAA) which is produced in oleander plants infected with Pseudomonas savastanoi (Magie, I963; Wilson, 1965). In culture, the organism rapidly converts tryptophan to IAA (Magie, Wilson \& Kosuge, I963; Kosuge, Heskett \& Wilson, 1966). Furthermore, certain isolates convert IAA to its lysine conjugate (Hutzinger \& Kosuge, 1968). Thus, systems that mediate the uptake of tryptophan and IAA and the exit of their metabolic products function in this organism (Hutzinger \& Kosuge, I968; Kuo \& Kosuge, I969). Knowledge of the properties of these transport systems would provide an insight to the manner in which the organism takes up host metabolites and releases its own metabolites into the surrounding host tissue during pathogenesis.

In this paper we describe some properties of tryptophan and IAA transport systems and discuss their possible roles in indole metabolism in this bacterium.

\section{METHODS}

Bacterium and culture. An isolate of Pseudomonas savastanoi (ATCC 23868) that is highly virulent to oleander and synthesizes indoleacetyl-lysine was used. The organism was maintained on King's Medium B (King, Ward \& Raney, 1954) at $4{ }^{\circ} \mathrm{C}$, and stock cultures were transferred at monthly intervals. For transport studies, bacteria were grown on a minimal medium which contained $(\mathrm{g} / \mathrm{l}): \mathrm{K}_{2} \mathrm{HPO}_{4}, \mathrm{I} \cdot 5 ; \mathrm{MgSO}_{4} \cdot 7 \mathrm{H}_{2} \mathrm{O}, 0.4 ;$ L-glutamine, 5 ; and D-glucose, IO. D-Glucose was autoclaved separately and added after the sterilized medium had cooled. The $\mathrm{pH}$ of the medium after autoclaving was approximately $7 \cdot 0$. 
Preparation of bacteria and determination of transport. Bacteria were grown in $100 \mathrm{ml}$ of the minimal medium in $250 \mathrm{ml}$ Erlenmeyer flasks on a rotary shaker at $25^{\circ} \mathrm{C}$ for approximately $20 \mathrm{~h}$. They were harvested by centrifuging for I min at $\mathrm{I} 4000 \mathrm{~g}$ at $4{ }^{\circ} \mathrm{C}$, rinsed twice with $15 \mathrm{ml}$ cold minimal medium, and resuspended in the minimal medium to the desired concentration (approximately $\mathrm{I} \cdot 5 \mathrm{mg}$ dry wt $/ \mathrm{ml}$ ). To minimize incorporation of tryptophan into protein, $20 \mu \mathrm{g}$ chloramphenicol/ml (final concentration) was added to the reaction mixture for tryptophan transport. The bacterial suspension and sterile minimal medium with varying concentrations of $\mathrm{L}-\left[{ }^{14} \mathrm{C}\right]$ tryptophan were equilibrated in"a water bath at $25^{\circ} \mathrm{C}$. Then $0 \cdot \mathrm{I} \mathrm{ml}$ of the bacterial preparation was mixed with $\mathrm{I} \cdot 4 \mathrm{ml}$ of the minimal medium. The mixture was stirred for $3 \mathrm{~s}$ on a Vortex mixer at low speed and then returned to the water bath at $25^{\circ} \mathrm{C}$. Thirty s after mixing, I $\mathrm{ml}$ of the reaction mixture was transferred to the centre of a Millipore filter (type HA, $0.45 \mu \mathrm{m}$ ). The bacteria on the filter were immediately washed with $5 \mathrm{ml}$ of the minimal medium at $25{ }^{\circ} \mathrm{C}$. The filter pads were removed, air dried, and placed in $5 \mathrm{ml}$ scintillation fluid (Patterson \& Greene, I965) and assayed with a liquid scintillation counter (Nuclear Chicago Model 6822).

To correct for non-specific adsorption, uptake was measured in bacteria treated with $30 \%$ $(\mathrm{v} / \mathrm{v})$ formaldehyde in water. The counts retained by the formaldehyde-treated bacteria were subtracted from the counts retained by untreated organisms to calculate net uptake of the compound tested. Transport rates are expressed as $\mu \mathrm{mol}$ of substrate taken up in $30 \mathrm{~s} / \mathrm{g}$ dry wt of bacteria.

Uptake of indoleacetic acid was measured in the same manner described for tryptophan except that chloramphenicol was omitted and the $\mathrm{pH}$ of the minimal medium was $6 \cdot 2$.

Osmotic shock treatment. A Io 1 carboy with 51 of minimal medium was inoculated with $100 \mathrm{ml}$ of a $20 \mathrm{~h}$ shaken culture of the bacterium. After vigorous aeration ( 5 to $71 \mathrm{air} / \mathrm{min}$ ) for $15 \mathrm{~h}$ at $25^{\circ} \mathrm{C}$, the cells were harvested in a Sharples centrifuge and osmotically shocked by the technique of Nossal \& Heppel (I966). The resulting osmotic shock fluid was concentrated by the addition of solid $\left(\mathrm{NH}_{4}\right)_{2} \mathrm{SO}_{4}$ to $95 \%(\mathrm{w} / \mathrm{v})$ of saturation with stirring at $4{ }^{\circ} \mathrm{C}$. The precipitate was collected by centrifuging for I5 min at $14000 \mathrm{~g}$ at $4{ }^{\circ} \mathrm{C}$, taken up in roo $\mathrm{ml}$ of O.oI M K-phosphate buffer $\left(4^{\circ} \mathrm{C}\right), \mathrm{pH} 7 \cdot 0$, and dialysed overnight against three 21 changes of the same buffer at $4{ }^{\circ} \mathrm{C}$. A sample ( $(\mathrm{I} 00 \mathrm{ml})$ of concentrated osmotic shock material was layered on a DEAE-cellulose (Cellex D, Biorad Lab) column $(2 \cdot 2 \times \mathrm{IO} \mathrm{cm})$ which had been equilibrated with $0 . \mathrm{I}$ M K-phosphate buffer, pH 6.9. The column was washed with $250 \mathrm{ml}$ of $0.02 \mathrm{M} \mathrm{K}$-phosphate buffer, $\mathrm{pH} 6.9$, followed by $250 \mathrm{ml}$ of $0.15 \mathrm{M} \mathrm{K}$-phosphate buffer, $\mathrm{pH}$ 6.9. Fractions were collected in $6 \mathrm{ml}$ portions and the extinction monitored at $280 \mathrm{~nm}$ to follow protein elution. Binding activity for tryptophan and IAA was detected by equilibrium dialysis (Penrose, Nichoalds, Piperno \& Oxender, 1968).

Buffer solutions. K-phosphate buffer was prepared from appropriate amounts of $\mathrm{KH}_{2} \mathrm{PO}_{4}$ and $\mathrm{K}_{2} \mathrm{HPO}_{4}$ to give a final phosphate concentration of $0.0 \mathrm{I} \mathrm{M}$ and desired $\mathrm{pH}$.

Chemicals. L-[Methylene- ${ }^{14} \mathrm{C}$ ]tryptophan, specific activity $54.5 \mathrm{mCi} / \mathrm{mmol}$, was purchased from Amersham-Searle. [Carboxy- ${ }^{14} \mathrm{C}$ ]indole-3-acetic acid was purchased from AmershamSearle, specific activity $48.5 \mathrm{mCi} / \mathrm{mmol}$, and Schwartz Bioresearch Inc., specific activity $14.2 \mathrm{mCi} / \mathrm{mmol}$. Other chemicals were purchased from commercial sources.:

\section{RESULTS}

Time course for uptake. When cells were incubated with either L-tryptophan or IAA, the initial rates of entry were rapid (Fig. I) and uptake was linear with time. Thereafter an apparent steady state of entry and exit was established. On the basis of these results, a $0.5 \mathrm{~min}$ incubation period was used to measure the approximate initial rate of entry. 


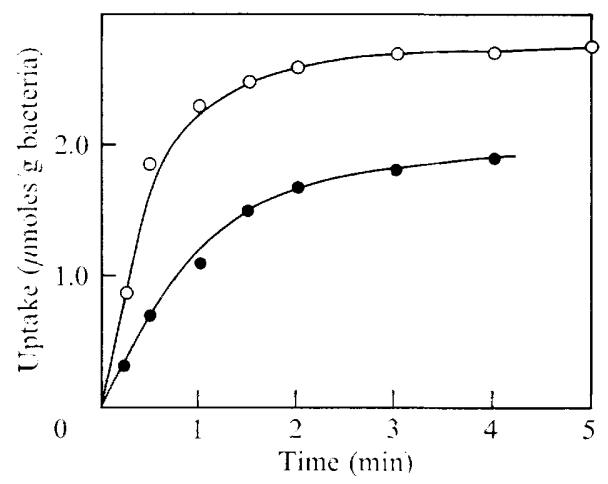

Fig. I

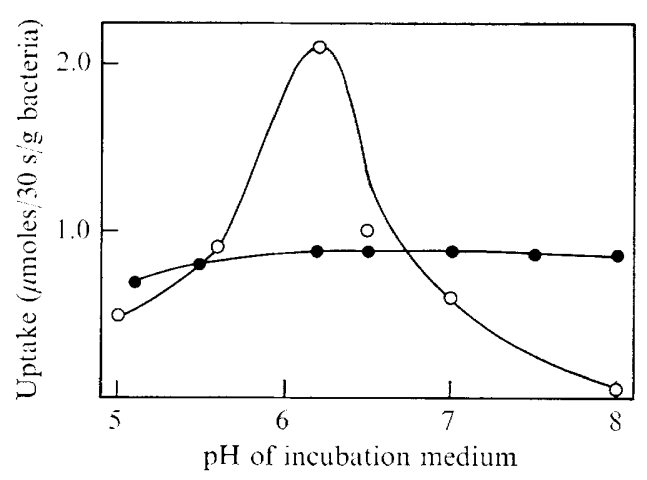

Fig. 2

Fig. I. Transport as a function of time. The external concentration of L-tryptophan (-O-) and IAA (-O-) was $0.1 \mathrm{~mm}$. Transport was measured as described in Methods except that the time was varied.

Fig. 2. pH Dependence of transport. Transport was measured as described in Methods except that the $\mathrm{pH}$ was varied. Potassium phosphate was used at all values listed. Because phosphate has low buffer capacity at the extremes of the $\mathrm{pH}$ range tested, $\mathrm{pH}$ values were measured after transport was conducted. In all cases the $\mathrm{pH}$ of the washing medium was the same as the $\mathrm{pH}$ of the incubation medium. External concentration of L-tryptophan (-O-) and IAA (-O-) was $0 \cdot 1 \mathrm{mM}$.

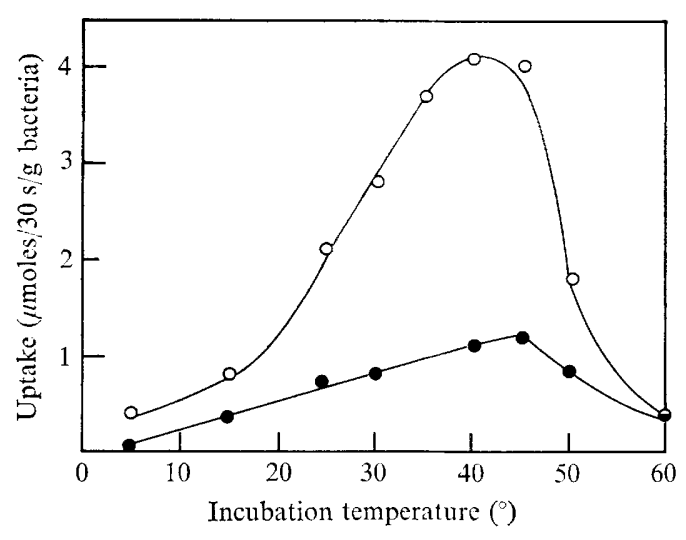

Fig. 3

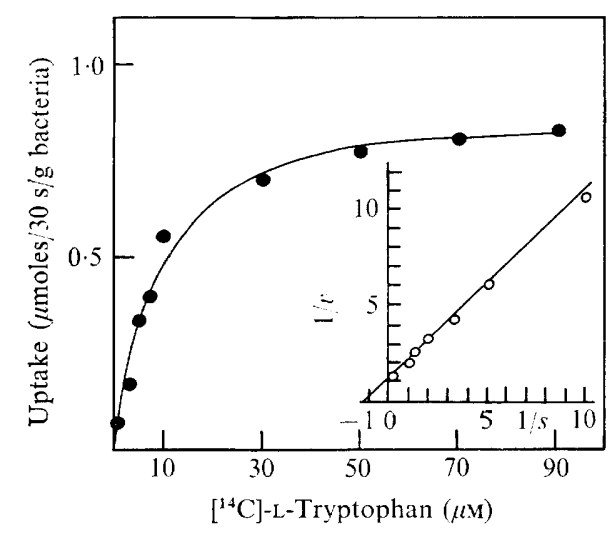

Fig. 4

Fig. 3. Temperature effect on transport. Transport was measured as described in Methods except that the temperature was varied. External concentration of L-tryptophan $\left(-O_{-}\right)$and IAA $\left(-\mathrm{O}_{-}\right)$ was $0 \cdot 1 \mathrm{~mm}$.

Fig. 4. Concentration dependence of L-tryptophan uptake. Inset: $v$ is $\mu$ mol L-tryptophan taken up per $30 \mathrm{~s}$ per $\mathrm{g}$ dry $\mathrm{wt}$ and $s$ is $\mu \mathrm{M}$-L-tryptophan.

pH Dependence of transport. Maximum uptake of tryptophan occurred over a broad $\mathrm{pH}$ range with no definite optimum (Fig. 2). In contrast, uptake of IAA occurred over a rather narrow $\mathrm{pH}$ range with a definite optimum at $6 \cdot 2$. Initial rates of transport measured in the presence of $0.01 \mathrm{M}$ tris- $\mathrm{HCl}$, for the $\mathrm{pH}$ range 7 to 9 , and $0.01 \mathrm{M} \mathrm{Na}$ citrate- $\mathrm{NaOH}$ buffer for $\mathrm{pH}$ range 4 to 6 were approximately $35 \%$ less than those observed when potassium phosphate was used over the same range.

Effect of temperature on transport. Uptake of tryptophan and IAA showed a pronounced temperature dependence (Fig. 3). Maximum uptake of tryptophan appeared to occur at approximately $45^{\circ} \mathrm{C}$, while the temperature optimum for IAA uptake was $40^{\circ} \mathrm{C} . Q_{10}$ values for tryptophan and IAA between $\mathrm{I} 5$ and $25^{\circ} \mathrm{C}$ were $2 \cdot \mathrm{I}$ and $2 \cdot 5$, respectively. 


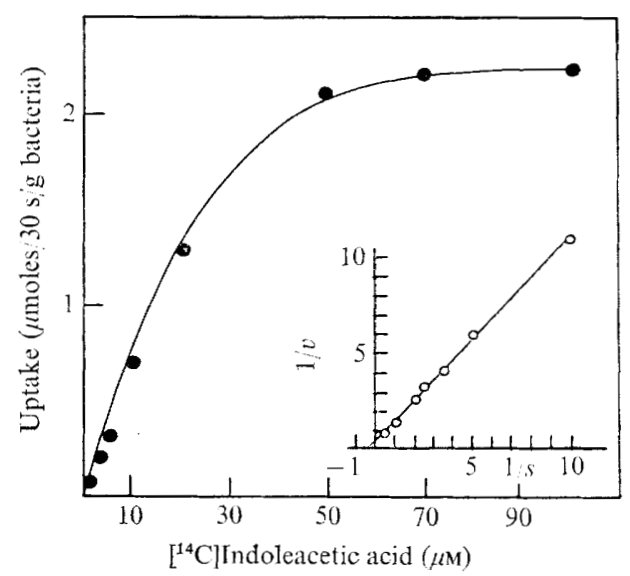

Fig. 5. Concentration dependence of indoleacetic acid uptake. Inset: $v$ is $\mu$ mol of indoleacetic acid taken up per 30 s per $g$ dry wt and $s$ is $\mu$ m indoleacetic acid.

Table I. Effect of amino acids on transport

\begin{tabular}{|c|c|c|}
\hline \multirow[b]{2}{*}{ Amino acid tested* } & \multicolumn{2}{|c|}{ Inhibition of transport $(\%) \dagger$} \\
\hline & Tryptophan & Indoleacetic acid \\
\hline Indoleacetic acid (control) & II & - \\
\hline L-Tryptophan (control) & - & o \\
\hline L-Histidine & 42 & 0 \\
\hline L-Serine & I4 & 20 \\
\hline L-Leucine & 13 & 13 \\
\hline L-Isoleucine & 12 & 13 \\
\hline L-Methionine & 12 & 0 \\
\hline Glycine & 12 & 0 \\
\hline L-Valine & II & 0 \\
\hline L-Alanine & 10 & 0 \\
\hline L-Arginine & 3 & 9 \\
\hline
\end{tabular}

* External concentration of L-tryptophan and indoleacetic acid and each potential competitor was $\mathrm{O} \cdot \mathrm{I} \mathrm{mM}$. The potential competitor and the appropriate substrate were mixed just prior to the addition of bacterial suspension.

Inhibition by L-glutamic acid, L-tyrosine, L-cysteine, L-threonine, hydroxy-L-proline, L-phenylalanine, L-lysine, L-aspartic acid, and L-proline was less than $8 \%$.

$\dagger$ Results are expressed as percentage of the control. The control rates $(\mu \mathrm{mol} / 30 \mathrm{~s} / \mathrm{g}$ dry wt bacteria) were 0.92 for L-tryptophan and 2.II for indoleacetic acid.

Concentration dependence of transport. Studies on other bacterial transport systems have shown that enzyme kinetics could be applied to describe the initial rates of uptake (Ames, I964; Piperno \& Oxender, I968). In our studies, the tryptophan transport system appeared to be nearly saturated at $20 \mu \mathrm{M}$ (Fig. 4) while the IAA transport system was saturated near $50 \mu \mathrm{M}$ (Fig. 5). The kinetic constants that describe the initial rates of entry were calculated from Lineweaver-Burk plots. The apparent $K_{m}$ values for tryptophan and IAA were $8 \mu \mathrm{M}$ and $20 \mu \mathrm{M}$, respectively, and the respective $V_{\max }$ values were 0.85 and $2.2 \mu \mathrm{mol} / 30 \mathrm{~s} / \mathrm{g}$ dry wt of bacteria.

Specificity of transport. When a compound is taken up by a bacterium it is presumed that in the initial stage it becomes associated with a specific site on the membrane surface (Pardee, 1968). Consequently, if two compounds are transported by the same system, and both are present in the extracellular medium, they would compete for this site, and the movement of 
Table 2. Effect of indole derivatives on transport

Compound tested*

Tryptophan (control)

Indoleacetic acid (control)

Indoleacetaldehyde

Indolepyruvic acid

Indoleacetonitrile

5-Hydroxy-indoleacetic acid

Indolelactic acid

Indoleacetamide

Indolecarbinol

Indoleproprionic acid

Indoleacetyl-lysine

Indole

Tryptamine
Inhibition of transport (\%) $\dagger$

Tryptophan Indoleacetic acid

\begin{tabular}{rr} 
II & \\
I I & 52 \\
35 & 48 \\
- & 48 \\
\hline 0 & 45 \\
I2 & 33 \\
5 & 28 \\
2 & 25 \\
4 & 24 \\
7 & 0 \\
7 & 0 \\
- & 0
\end{tabular}

* External concentration of L-tryptophan and indoleacetic acid and each potential competitor was $0 \cdot I \mathrm{~mm}$ each. The potential competitor and the appropriate substrate were mixed just prior to the addition of cell suspension.

$\dot{\dagger}$ Results are expressed as percentage of the control. The rates $(\mu \mathrm{mol} / 30 \mathrm{~s} / \mathrm{g}$ dry wt) were I.05 for Ltryptophan and $2 \cdot 15$ for indoleacetic acid.

\section{Table 3. Effect of tryptophan derivatives on tryptophan transport}

\begin{tabular}{lr}
\multicolumn{1}{l}{ Compound tested* } & Inhibition of tra \\
L-Tryptophan (control) & - \\
DL-5-Hydroxy-tryptophan & 38 \\
DL-5-Methyl-tryptophan & 32 \\
DL-4-Methyl-tryptophan & 29 \\
DL-6-Methyl-tryptophan & 27 \\
DL- $\alpha$-Methyl-tryptophan & IO \\
D-Tryptophan & 9
\end{tabular}

* External concentration of L-tryptophan was O.I mM; D-tryptophan was O.I mM; each DL derivative was $0.2 \mathrm{mM}$. L-Tryptophan and the compound to be tested were mixed together just prior to the addition of cell suspension.

$\dagger$ Results are expressed as percent inhibition of control which was $0.95 \mu \mathrm{mol} / 30 \mathrm{~s} / \mathrm{g}$ dry wt bacteria.

Table 4. Effect of metabolic inhibitors

Incubation conditions* $\overbrace{\text { Tryptophan Indoleacetic acid }}^{\text {Inhibition of transport } \% \uparrow}$

Control

2,4-Dinitrophenol

$\begin{array}{rr}\overline{88} & - \\ 85 & 90 \\ 0 & 85 \\ 0 & 4 \\ 0 & 4\end{array}$

EDTA

$N$-Ethyl maleimide

90

85

4

* External concentration of tryptophan and IAA was 0.I mM; the concentration of each inhibitor was I mM.

$\dot{\dagger}$ Results are expressed as percentage inhibition of control which contained no inhibitor. The control rates $(/ \mathrm{mol} / 30 \mathrm{~s} / \mathrm{g}$ dry wt bacteria) were 0.90 for L-tryptophan and $2 \cdot$ I I for indoleacetic acid. 


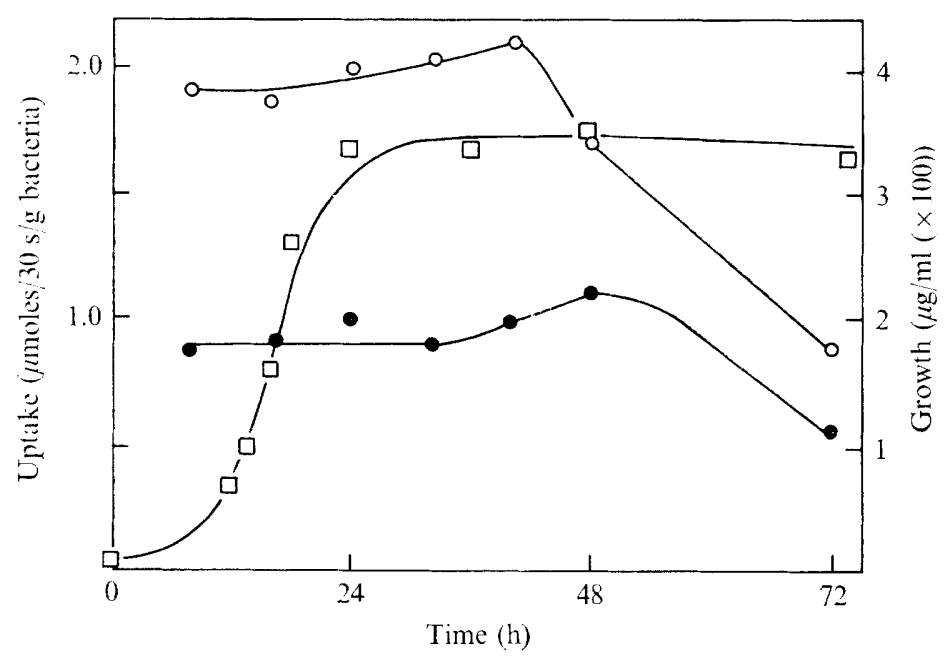

Fig. 6. Effect of the age of culture on transport rates. Pseudomonas savastanoi was grown on minimal medium $(500 \mathrm{ml})$ on a rotary shaker at $25^{\circ} \mathrm{C}$. At $8 \mathrm{~h} 100 \mathrm{ml}$ of suspension and $50 \mathrm{ml}$ at each interval thereafter were removed and transport measured as described in Methods. External concentration of L-tryptophan (--) and IAA (-O-) was O.I mM. Growth (- $\square-)$ was determined turbidimetrically.

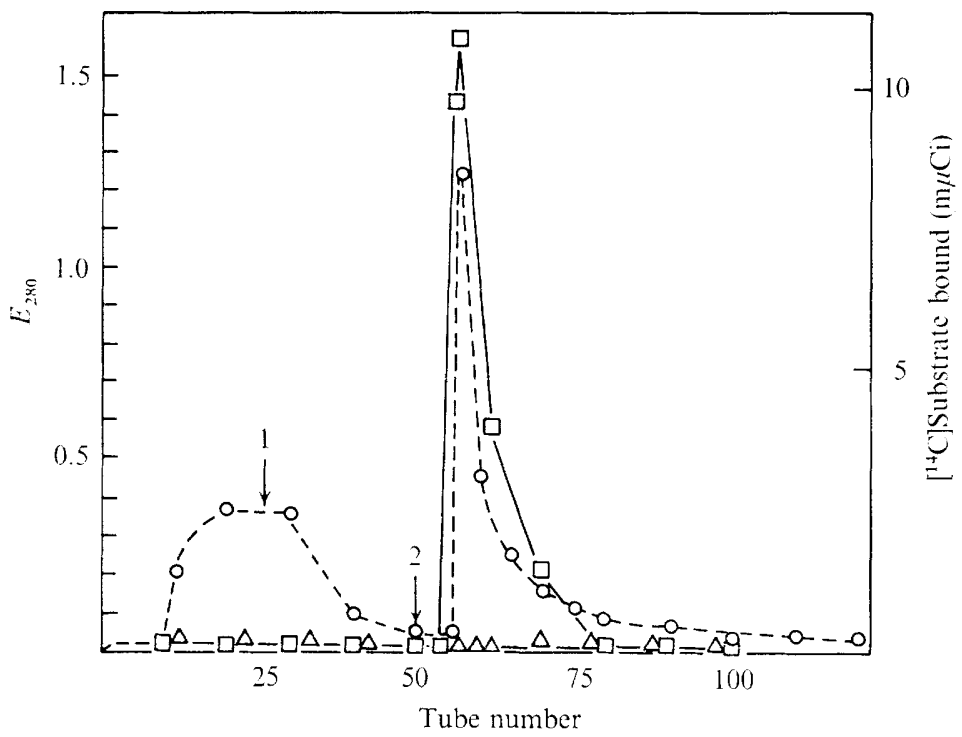

Fig. 7. Separation of indoleacetic acid-binding activity from osmotic shock material by chromatography on a DEAE-cellulose column. The column was eluted first with $0.02 \mathrm{M}$-potassium phosphate, pH 6.9 (arrow I) and then with 0.I 5 M-potassium phosphate, $\mathrm{pH} 6.9$ (arrow 2). The fraction volume was $6 \mathrm{ml}$ and the flow rate was $3 \mathrm{ml} / \mathrm{min} . E_{280}\left(-\bigcirc^{-}\right)$, indoleacetic acid-binding activity $\left(-\square^{-}\right)$, tryptophan-binding activity $(-\triangle-)$. Binding activity in the column effluents was determined by the equilibrium dialysis procedure of Penrose et al. (I968) except that 0.1 mM L-tryptophan- $-{ }^{14} \mathrm{C}$ (specific activity, I $\mu \mathrm{Ci} / \mu \mathrm{mol}$ ) or $0^{\cdot} \mathrm{I}$ mM-indoleacetic acid- $3^{-14} \mathrm{C}$ (specific activity, I $\mu \mathrm{Ci} / \mu \mathrm{mol}$ ) was used as substrate. 


\section{Table 5. Transport by osmotically shocked bacteria}

Bacteria were grown in 51 of minimal medium and harvested by centrifugation as described in Methods. The cells were washed twice with $10 \mathrm{ml}$ of $0.03 \mathrm{M}-\mathrm{NaCl}$ buffered with $0.0 \mathrm{I} \mathrm{M}$ tris- $\mathrm{HCl}$, $\mathrm{pH} 7 \cdot 2 / \mathrm{g}$ of wet bacteria. For control organisms a portion $(10 \mathrm{ml})$ of the washed bacteria was mixed with Io $\mathrm{ml}$ of cold minimal medium, centrifuged for $\mathrm{I}$ min at $14000 \mathrm{~g}$ at $4{ }^{\circ} \mathrm{C}$ and resuspended in minimal medium to the desired bacterial concentration. 'Shocked' organisms were prepared by subjecting the remainder of the washed bacteria to osmotic shock treatment (Nossal \& Heppel, 1966). After removal of the osmotic shock fluid, bacteria were suspended in cold minimal medium to the desired concentration. Transport studies were conducted at $25^{\circ} \mathrm{C}$ with $30 \mathrm{~s}$ incubation of cell suspension with labelled substrates.

$\begin{array}{lcc}\text { Bacterial treatment } & \overbrace{\begin{array}{c}\text { Tryptophan } \\ \mu \mathrm{mol} / 30 \mathrm{~s} / \mathrm{g} \text { dry wt, bacteria }\end{array}}^{\text {Transport rates }} \\ \text { Control } & \mathbf{I} \cdot 0 & 2.2 \\ \text { Shocked } & 0.85 & 0.8\end{array}$

one into the cell would be decreased in the presence of the other. Therefore, with whole organism preparations specificity of transport is determined by measuring the rate of uptake in the presence of potential competitors. We found that of several amino acids tested only L-histidine had affinity for the tryptophan transport system (Table I). The uptake of IAA, moreover, was apparently not associated with the transport of tryptophan since it failed to inhibit uptake of the amino acid. Indolepyruvicacid (Table 2) was the only indole derivative that apparently competed with both transport systems, while no effect on either system was observed with indoleacetyl-lysine, indole, and tryptamine. All other indole derivatives (Table 2) that inhibited IAA transport had no effect on tryptophan transport. Of the tryptophan derivatives only DL- $\alpha$-methyl-tryptophan and D-tryptophan (Table 3 ) failed to inhibit trytophan transport. EDTA and $N$-ethyl maleimide did not inhibit transport of either compound whereas 2,4-dinitrophenol and sodium azide did (Table 4).

Effect of culture age on transport rates. Since many metabolic processes vary with the time of bacterial growth it seemed reasonable to assume that transport rates could also vary in this way. Fig. 6 shows that transport rates were near maximal in the earliest samples harvested $(8 \mathrm{~h})$ and remained high until about 40 to $48 \mathrm{~h}$ growth, after which they rapidly declined. These results indicated that a growth period of $20 \mathrm{~h}$ could be used for transport studies.

Experiments with osmotically shocked cells. Osmotic shock decreased IAA transport but had little effect on tryptophan transport (Table 5). Moreover, factors that bind IAA were released from the bacteria and detected in the osmotic shock fluid. By DEAE-cellulose chromatography, a fraction that binds IAA was recovered from the shock fluid (Fig. 7). No tryptophan binding activity was detected in the osmotic shock fluid or in the DEAE column effluents.

Effect of preloading cells with tryptophan and indoleacetic acid. IAA inhibited its own formation from L-trytophan by bacterial suspensions (Kuo \& Kosuge, 1969). This was attributed to either (i) inhibition of tryptophan oxidative decarboxylase, which catalyses the conversion of tryptophan to indoleacetamide or (ii) inhibition of tryptophan uptake. In the present study IAA did not inhibit the uptake of tryptophan directly. However, when cells were loaded with L-tryptophan, rates of transport of tryptophan and IAA decreased (Table 6). Similarly, transport of IAA, as well as its precursor tryptophan, was inhibited when cells were loaded with IAA. 


\title{
Table 6. Effects of pre-incubation conditions on the transport of L-tryptophan and indoleacetic acid
}

\begin{abstract}
Bacteria were grown in minimal medium and harvested as described in Methods. The cells were washed twice with Io $\mathrm{ml}$ of $0.03 \mathrm{M}-\mathrm{NaCl}$ buffered with $0.01 \mathrm{M}$-tris- $\mathrm{HCl}, \mathrm{pH} 7 \cdot 2 / \mathrm{g}$ of wet bacteria and suspended in $10 \mathrm{ml}$ of cold $\left(4^{\circ} \mathrm{C}\right)$ minimal medium to a concentration of $3 \mathrm{mg}$ dry wt $/ \mathrm{ml}$. Then $\mathrm{I} O \mathrm{ml}$ of the latter bacterial suspension were mixed with $\mathrm{I} 0 \mathrm{ml}$ of cold minimal medium containing Io mM-L-tryptophan (pre-incubation with tryptophan), or indoleacetic acid (pre-incubation with indoleacetic acid). After $15 \mathrm{~min}$ the cell preparations were centrifuged for I min at $14000 \mathrm{~g}$ at $4{ }^{\circ} \mathrm{C}$. The sedimented bacteria were washed once with $20 \mathrm{ml}$ cold minimal medium and then resuspended in minimal medium at $25^{\circ} \mathrm{C}$ to a concentration of $\mathrm{I} \cdot 5 \mathrm{mg}$ dry wt $/ \mathrm{ml}$. The suspension was used for transport studies in $0^{\cdot} \mathrm{I}$ mM-tryptophan or $\left[{ }^{14} \mathrm{C}\right]$ indoleacetic acid by procedures described in Methods. Transport rates, $\mu \mathrm{mol}$ of substrate taken up per $30 \mathrm{~s} / \mathrm{g}$ dry wt of cells, are expressed relative to the control rates which were 0.95 for L-tryptophan and $2 \cdot \mathrm{I}$ for indoleacetic acid.
\end{abstract}

Bacterial treatment

No treatment (control)

Pre-incubation with indoleacetic acid

Pre-incubation with tryptophan

\begin{tabular}{cc}
\multicolumn{2}{c}{ Relative transport rates } \\
Tryptophan & Indoleacetic acid \\
I00 & I00 \\
64 & 60 \\
59 & 54
\end{tabular}

\section{DISCUSSION}

The transport of tryptophan and other amino acids has been studied in bacteria (Boezi \& DeMoss, 196r; Ames, 1964; Piperno \& Oxender, 1968; Kaback, I970) and fungi (Wiley \& Matchett, 1966). The presence of transport systems which mediate the uptake of organic acids has been suggested (Shilo \& Stanier, I957; Clarke \& Meadow, I959) and systems for the uptake of citric acid by Streptococcus diacetilactis (Harvey \& Collins, 1962) and malate by $S$. faecalis (London \& Meyer, 1970) have been reported but no reports dealing with IAA transport have appeared.

When Pseudomonas savastanoi is grown in a medium containing tryptophan or IAA, the first reaction in the utilization of either compound is its transport into the bacterium. If the proposed mechanism of transport in other bacteria is correct (Pardee, 1968), the first step is formation of a complex between tryptophan or IAA and a specific component on the outer membrane surface. Specificity of such binding would therefore serve to regulate tryptophan and IAA metabolism. Since incubation of the bacterium with either L-tryptophan or IAA decreases the subsequent rate of transport of either compound (Table 6), additional, as yet uncharacterized, regulatory mechanisms also appear to help control entry of the two compounds into the cell.

Sufficient differences are noted between IAA transport and tryptophan transport to indicate that separate systems are involved. This is further substantiated by the removal of an IAA-binding factor from cells by osmotic shock and its isolation by DEAE-cellulose chromatography. Tryptophan-binding activity was not removed by this treatment.

The tryptophan transport system appears to be stereospecific as shown by the lack of inhibition of uptake of L-tryptophan by D-tryptophan. Divalent cations do not appear to be involved in the transport of either tryptophan or IAA since EDTA did not inhibit uptake. Moreover, the lack of inhibition of transport by $N$-ethyl maleimide suggests that the initial binding process does not involve a thiol group. The transport processes may be energydependent since uptake of both compounds was strongly inhibited by sodium azide and 2,4-dinitrophenol. However, direct involvement of an energy-rich compound in the transport system is not likely since an incubation period was required in order to observe decreased transport rates. 
Both IAA and tryptophan transport systems are characterized by low $K_{m}$ values. Such values are in keeping with those observed in other bacterial transport systems and offer an obvious advantage to a plant pathogen since in nature it may encounter many carbon and nitrogen compounds in low concentration that it can use as nutrients. Since the low $K_{m}$ values for tryptophan reflect high affinity of the organism for this compound, it follows that this bacterium possesses the capacity effectively to scavenge any tryptophan that it encounters in host tissue. At present we have no information on tryptophan concentration in oleander or olive tissue but it is reasonable to expect in many plants concentrations in the range of the $K_{m}$ value $(8 \mu \mathrm{M})$ for tryptophan transport in this bacterium.

This work was supported by U.S. Public Health Service Grant no. AI-o6323 from the Institute of Allergies and Infectious Diseases.

\section{REFERENCES}

Ames, G. F. (1964). Uptake of amino acids by Salmonella typhimurium. Archives of Biochemistry and Biophysics 104, I-I 8 .

Boezı, J. A. \& DeMoss, R. D. (196I). Properties of a tryptophan transport system in Escherichia coli. Biochimica et biophysica acta 49, 47I-484.

Clarke, P. H. \& MEadow, P. M. (1959). Evidence for the occurrence of permeases for tricarboxylic acid cycle intermediates in Pseudomonas aeruginosa. Journal of General Microbiology 20, 144-155.

Harvey, R. J. \& Collins, E. B. (1962). Citrate transport system of Streptococcus diacetilactis. Journal of Bacteriology 83, $1005-1009$.

Hutzinger, O. \& Kosuge, T. (1968). Microbial synthesis and degradation of indole-3-acetic acid. III. The isolation and characterization of indole-3-acetyl- $\epsilon$-L-lysine. Biochemistry 7, 60I-605.

KaBACK, H. R. (1970). Transport. Annual Review of Biochemistry 39, 56I-598.

KING, E. O., WARD, M. K. \& RANEY, D. E. (1954). Two simple media for the demonstration of pyocyanin and fluorescin. Journal of Laboratory and Clinical Medicine 44, 30I-307.

Kosuge, T., Heskett, M. G. \& WiLSON, E. E. (1966). Microbial synthesis and degradation of indole-3-acetic acid. I. The conversion of L-tryptophan to indole-3-acetamide by an enzyme system from Pseudomonas savastanoi. Journal of Biological Chemistry 241, 3738-3744.

Kuo, T. T. \& KosugE, T. (I969). Factors influencing the production and further metabolism of indole-3-acetic acid by Pseudomonas savastanoi. Journal of General and Applied Microbiology 15, 5I-63.

LONDON, J. \& MEYER, E. Y. (1970). Malate utilization by a group D streptococcus: regulation of malic enzyme synthesis by an inducible malate permease. Journal of Bacteriology 102, I30-137.

MAGIE, A. R. (1963). Physiological factors involved in tumor production by the oleander knot pathogen,

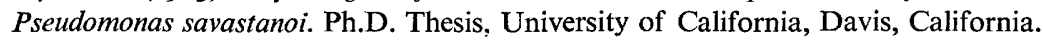

MAGIE, A. R., WiLson, E. E. \& Kosuge, T. (I963). Indoleacetamide as an intermediate in the synthesis of indoleacetic acid in Pseudomonas savastanoi. Science, New York I4r, I281-I 282.

Nossal, N. G. \& Heppel, L. A. (1966). The release of enzymes by osmotic shock from Escherichia coli in exponential phase. Journal of Biological Chemistry 24r, 3055-3062.

PardeE, A. B. (1968). Membrane transport proteins. Science, New York 162, 632-637.

Patterson, M. S. \& Greene, R. C. (1965). Measurement of low energy beta-emitters in aqueous solution by liquid scintillation counting of emulsions. Analytical Chemistry 37, 854-857.

Penrose, W. R., Nichoalds, G. E., Piperno, J. R. \& OXender, D. L. (1968). Purification and properties of a leucine-binding protein from Escherichia coli. Journal of Biological Chemistry 243, 592 I-5928.

PIPERNO, J. R. \& OXENDER, D. L. (1968). Amino acid transport systems in Escherichia coli K I 2. Journal of Biological Chemistry 243, 5914-5920.

Shilo, M. \& Stanier, R. Y. (I957). The utilization of the tartaric acids by pseudomonads. Journal of General Microbiology 16, 482-490.

Wiley, W. R. \& MATCHETT, W. H. (1966). Tryptophan transport in Neurospora crassa. I. Specificity and kinetics. Journal of Bacteriology 92, 1698-1705.

WiLson, E. E. (1965). Pathological histogenesis in oleander tumors induced by Pseudomonas savastanoi. Phytopathology 55, I244-I 249. 